\title{
Autoradiographic Localization of Putative Nicotinic Receptors in the Rat Brain Using ${ }^{125}$-Neuronal Bungarotoxin
}

\author{
David W. Schulz, ${ }^{a}$ Ralph H. Loring, ${ }^{b}$ Elias Aizenman, ${ }^{\mathrm{c}}$ and Richard E. Zigmond \\ Departments of Biological Chemistry and Molecular Pharmacology and Neurology, Harvard Medical School, Boston, \\ Massachusetts 02115, Childrens Hospital Medical Center, Boston, Massachusetts 02115, and Department of \\ Neurosciences, Case Western Reserve University, School of Medicine, Cleveland, Ohio 44106
}

Neuronal bungarotoxin (NBT), a snake venom neurotoxin, selectively blocks nicotinic receptors in many peripheral and central neuronal preparations. $\alpha$-Bungarotoxin ( $\alpha \mathrm{BT}$ ), on the other hand, a second toxin isolated from the venom of the same snake, is an ineffective nicotinic antagonist in most vertebrate neuronal preparations studied thus far. To examine central nicotinic receptors recognized by NBT, we have characterized the binding of ${ }^{125}$-labeled NBT ( ${ }^{125} \mid-N B T$ ) to rat brain membranes and have mapped the distribution of ${ }^{25}$ I-NBT binding in brain sections using quantitative light microscopic autoradiography.

The binding of ${ }^{125}$-NBT was found to be saturable, of high affinity, and heterogeneously distributed in the brain. Pharmacological studies suggested that more than one population of sites is labeled by ${ }^{25}$ I-NBT. For example, one component of ${ }^{125} \mathrm{~J}-\mathrm{NBT}$ binding was also recognized by $\alpha \mathrm{BT}$, while a second component, not recognized by $\alpha \mathrm{BT}$, was recognized by the nicotinic agonist nicotine. The highest densities of these $\alpha \mathrm{BT}$-insensitive, nicotine-sensitive sites were found in the fasciculus retroflexus, the lateral geniculate nucleus, the medial terminal nucleus of the accessory optic tract, and the ollvary pretectal nucleus. $\alpha B T$-sensitive NBT binding sites were found in highest density in the lateral geniculate nucleus, the subthalamic nucleus, the dorsal tegmental nucleus, and the medial mammillary nucleus (lateral part).

The number of brain regions with a high density of ${ }^{125} \mid-$ NBT binding sites, blocked either by $\alpha B T$ or by nicotine, is low when compared with results obtained using other approaches to studying the central distribution of nicotinic receptors, such as labeling with ${ }^{3} \mathrm{H}$-nicotine or labeling with CDNA probes to mRNAs coding for putative receptor subunits. It is proposed that ${ }^{125}$-NBT labels a subpopulation of nicotinic receptors in the rat brain, and that, given its ability

\footnotetext{
Received Apr. 2, 1990; revised Sept. 5, 1990; accepted Sept. 11, 1990.

This work was supported by NIH Grants NS12651 and NS22472. D.W.S. was a Pharmaceutical Manufacturers Association Foundation Fellow in Pharmacology-Morphology, and R.E.Z. is the recipient of National Institute of Mental Health Research Scientist Award MH00162. We wish to thank Dr. Frost White for assistance in initiating these autoradiographic experiments and Dr. James Unnerstall for his critical reading of the manuscript.

Correspondence should be addressed to Dr. Richard Zigmond, Department of Neurosciences, Case Western Reserve University, School of Medicine, $2119 \mathrm{Ab}$ ington Road, Cleveland, $\mathrm{OH} 44106$.

a Present address: Pfizer Central Research, Groton, CT 06340.

b Present address: Department of Pharmacology, Northeastern University, Boston, MA 02115.

' Present address: Department of Physiology, University of Pittsburgh, Pittsburgh, PA 15261.

Copyright (C) 1991 Society for Neuroscience 0270-6474/91/010287-11\$03.00/0
}

to block nicotinic receptors in a variety of neuronal preparations, NBT will be a useful probe for studying the functional properties of these sites.

It is now clear that nicotinic, as well as muscarinic, receptors mediate the effects of $\mathrm{ACh}$ in the CNS. Nicotinic receptors have been linked to a variety of central cholinergic effects, including locomotor activity (Clarke and Kumar, 1983), antinociception (Sahley and Berntson, 1979; Tripathi et al., 1982), and intracranial self-stimulation (Pradhan and Bowling, 1971). Nicotinic agonists elicit excitatory electrophysiological responses that are blocked by classical ganglionic nicotinic antagonists (e.g., mecamylamine) in many different brain regions, including the substantia nigra pars compacta and the ventral tegmental area (Clarke et al., 1985a; Grenhoff et al., 1986), the caudate-putamen (Misgeld et al., 1980), the interpeduncular nucleus (Brown et al., 1983), the medial habenula (McCormick and Prince, 1987), the locus coeruleus (Egan and North, 1986), and the hypothalamus (Hatton et al., 1983). Recent postmortem studies of brains removed from patients who had suffered from Alzheimer's disease have suggested that nicotinic receptors are selectively depleted in certain regions of the CNS (Nordberg and Winblad, 1986; Shimohama et al., 1986; Whitehouse et al., 1986), consistent with the idea that a change in central nicotinic neurotransmission might underlie some of the neurological deficits that accompany this condition.

Several approaches have been used previously to study the neuroanatomical distribution of central nicotinic receptors. Immunohistochemical localization of putative nicotinic receptors in the rat brain has been accomplished using monoclonal antibodies raised against nicotinic receptors immunoaffinity purified from the chick brain (monoclonal antibody 270; Deutch et al., 1987; Swanson et al., 1987). cDNAs coding for putative $\alpha$ and $\beta$ subunits of central nicotinic receptors have been cloned, and in situ hybridization techniques have been used to localize the corresponding mRNAs in the brain (Boulter et al., 1986; Goldman et al., 1986, 1987; Wada et al., 1989). An autoradiographic approach using ${ }^{14} \mathrm{C}$-labeled 2-deoxyglucose has been employed to determine which areas in the brain become metabolically active following parenteral administration of nicotine (Pazdernik et al., 1982; London et al., 1988). Finally, binding studies have attempted to label nicotinic receptors autoradiographically by utilizing radiolabeled analogs of the following nicotinic ligands: ACh (Rainbow et al., 1984; Clarke et al., 1985b), nicotine (Clarke et al., 1984, 1985b; London et al., 1985), and $\alpha$-bungarotoxin ( $\alpha$ BT; Arimatsu et al., 1978; Hunt and Schmidt, 1978; Segal et al., 1978; Clarke et al., 1985b). 
Of these different methodologies, in vitro autoradiography is most appropriate for obtaining quantitative measures of receptor density, because binding sites may be labeled directly. With all studies using this approach, of course, one must be concerned as to whether the binding sites being measured using a particular ligand correspond, in fact, to functional receptors. For example, tritium-labeled nicotinic agonists label binding sites with nanomolar affinities, while micromolar concentrations of these agonists are required to evoke physiological responses. Such findings raise questions as to whether the labeled sites are, in fact, nicotinic receptors, though these high-affinity sites could represent desensitized states of the receptors (reviewed by Lindstrom et al., 1987; Schmidt, 1988). A second problem encountered when using tritium-labeled compounds is that it is often difficult to obtain accurate quantitative data, due to quenching of $\beta$ particles by white matter (Kuhar and Unnerstall, 1985).

$\alpha \mathrm{BT}$ is a potent antagonist of nicotinic synaptic transmission at the neuromuscular junction and has been useful in characterizing nicotinic receptors in muscle (reviewed by Popot and Changeux, 1984). However, interpretation of experiments using ${ }^{125} \mathrm{I}-\alpha \mathrm{BT}$ to study nicotinic receptors in the brain is made difficult by repeated observations that $\alpha \mathrm{BT}$ fails to antagonize nicotinic function in almost all neuronal preparations that have been examined (reviewed by Schmidt et al., 1980; Lindstrom et al., 1987; Loring and Zigmond, 1988), though a few exceptions have been reported (Marshall, 1981; Zatz and Brownstein, 1981; Farley et al., 1983; de la Garza, 1987). Therefore, there is clearly a need for a radiolabeled antagonist of high specific activity that recognizes functional nicotinic receptors with high affinity.

In 1979 , a peptide toxin distinct from $\alpha$ BT was purified from the venom of the snake Bungarus multicinctus (Ravdin and Berg, 1979). This toxin, which has been referred to as bungarotoxin 3.1 (Ravdin and Berg, 1979), toxin F (Loring et al., 1983), and $\kappa$-bungarotoxin (Chiappinelli, 1983), was found to block potently nicotinic activity in chick and rat autonomic ganglia (Ravdin and Berg, 1979; Chiappinelli, 1983; Loring et al., 1983, 1984; Chiappinelli and Dryer, 1984; Sah et al., 1987), with $\mathrm{IC}_{50}$ values of $<100 \mathrm{nM}$. In contrast, this toxin is very poor at blocking nicotinic receptors at the neuromuscular junction and, thus, has a selectivity for neuronal versus muscle nicotinic receptors that is opposite to that of $\alpha \mathrm{BT}$. Bungarotoxin 3.1, toxin $\mathrm{F}$, and $\kappa$-bungarotoxin are now known to be the same toxin (Loring et al., 1986), and it has been suggested that the name "neuronal bungarotoxin" (NBT) be used to refer to this molecule (Lindstrom et al., 1987).

In the chick ciliary ganglion, NBT antagonizes the depolarizations caused by application of nicotinic agonists, as well as the nicotinic responses evoked by presynaptic stimulation (Loring et al., 1984). Thus, it is likely that NBT acts at postsynaptic nicotinic receptors in this preparation. In addition, because NBT's long-lasting blocking effects in autonomic neurons are prevented by co-applying the rapidly reversible antagonists dihydro- $\beta$-erythroidine (Sah et al., 1987) or $d$-tubocurare (Chiappinelli, 1983), it appears that NBT acts at the same site on the receptor as do classical competitive nicotinic antagonists.

In order to study its binding in autonomic ganglia, NBT has been labeled with ${ }^{125}$ I ( ${ }^{125}$ I-NBT). It was found that a portion of high-affinity ${ }^{125} \mathrm{I}-\mathrm{NBT}$ binding sites is recognized by $\alpha \mathrm{BT}$, while a second component is selective for NBT (Chiappinelli, 1983; Loring et al., 1984; Sah et al., 1987). Because $\alpha$ BT fails to block nicotinic activity in autonomic ganglia, it has been proposed that it is this second component that corresponds to functional nicotinic receptors (Loring et al., 1984; Loring and Zigmond, 1988). Interestingly, electron microscopic studies of chick ciliary ganglia and cultured rat sympathetic neurons have established that the NBT-selective sites are preferentially concentrated at synaptic regions (Loring and Zigmond, 1987; Loring et al., 1988).

In addition to blocking nicotinic transmission in peripheral autonomic ganglia, NBT has been shown to block nicotinic responses in the chick (Loring et al., 1989) and rat (Lipton et al., 1987; Aizenman et al., 1990) retina. These results raised the possibility that NBT might be useful more generally in studying central nicotinic transmission. In support of this idea, we have discovered that NBT blocks the nicotine-evoked release of endogenous dopamine from slices of the rat striatum (Schulz and Zigmond, 1989). Blockade by NBT of physiological responses mediated by neuronal nicotinic receptors in other central preparations has also been reported recently (de la Garza et al., 1989; Vidal and Changeux, 1989; Wong and Gallagher, 1989).

In the present study, we have used light-microscopic autoradiography to examine the distribution of ${ }^{125} \mathrm{I}-\mathrm{NBT}$ binding in the rat brain. Studies in membrane preparations, which were done in order to determine whether ${ }^{125} \mathrm{I}-\mathrm{NBT}$ is an appropriate high-affinity ligand for nicotinic receptors in the rat brain, are also reported.

Certain of these data have been presented to the Society for Neuroscience (Schulz et al., 1988).

\section{Materials and Methods}

NBT was purified from Bungarus multicinctus venom (a gift from Biotoxins Inc., St. Cloud, FL) as described previously (Loring et al., 1986). A chloramine-T procedure (Loring and Zigmond, 1987) was used to label the toxin with ${ }^{125} \mathrm{I}$. The resulting specific activity of ${ }^{125}$ I-NBT ranged from 700 to $1300 \mathrm{Ci} / \mathrm{mmol}$.

Binding to membrane preparations. Preliminary receptor binding studies utilized membranes prepared from rat corpora striata, because we had previously characterized the functional properties of NBT using this region of the brain (Schulz and Zigmond, 1989). Adult male SpragueDawley rats were decapitated, and the striata were rapidly dissected from the brain on ice. Tissue was either used immediately or stored frozen at $-20^{\circ} \mathrm{C}$, with no differences in binding observed for the 2 procedures. The tissue was homogenized in 20 vol of ice-cold buffer using a Brinkmann Polytron (Westbury, NY) at setting 6 for $20 \mathrm{sec}$ and washed twice by centrifuging at $25,000 \times \mathrm{g}$, and the pellet was resuspended at a tissue concentration of $60 \mathrm{mg}$ wet weight $/ \mathrm{ml}$. The buffer contained $120 \mathrm{~mm} \mathrm{NaCl}, 50 \mathrm{~mm}$ Tris $(\mathrm{pH}, 7.4)$, and $2 \mathrm{mg} / \mathrm{ml}$ bovine serum albumin (BSA). Fifty-microliter aliquots of tissue suspension were preincubated with $50 \mu \mathrm{l}$ of buffer alone or with a competing ligand for $30 \mathrm{~min}$ in $12 \times 75-\mathrm{mm}$ polypropylene culture tubes (Fisher Scientific, Pittsburgh, PA). The binding reaction was then initiated by adding $50 \mu{ }^{125}$ I-NBT at a concentration 3 times the desired final concentration. Nonspecific binding was defined as binding in the presence of $0.5 \mu \mathrm{M}$ nonradioactive NBT. The tubes were incubated at $37^{\circ} \mathrm{C}$ for $1 \mathrm{hr}$ (unless noted otherwise), and the reaction was terminated by dilution with $4 \mathrm{ml}$ cold buffer and immediate filtration onto Whatman $\mathrm{GF} / \mathrm{C}$ filters that had been presoaked in cold buffer. Filters were washed twice more with $4 \mathrm{ml}$ cold buffer containing $0.1 \mathrm{mg} / \mathrm{ml} \mathrm{BSA}$ and counted in a Beckman 300 gamma counter at $60 \%$ efficiency. Quadruplicate determinations were made for each condition within a given experiment. Protein content was determined by the method of Lowry et al. (1951) using BSA as the standard.

Autoradiography experiments. Adult male Sprague-Dawley rats were anesthetized with chloral hydrate $(35 \%, 0.14 \mathrm{ml} / 100 \mathrm{gm})$ and perfused with phosphate-buffered isotonic sucrose. Brains were frozen onto cryostat chucks, and $20-\mu \mathrm{m}$ sections were cut, thaw mounted onto glass slides, and stored at $-20^{\circ} \mathrm{C}$ until they were used. The procedure for incubating and washing tissue sections was adapted from earlier studies that had used ${ }^{125}$ I- $\alpha$ BT as a radioligand (Arimatsu et al., 1978; Clarke et al., 1985b). Sections were preincubated with or without nonradioactive compounds at room temperature for $30 \mathrm{~min}$ in Tris-buffered saline with BSA (see above). The sections were then incubated at $37^{\circ} \mathrm{C}$ in 
Table 1. Quantitative analysis of regional ${ }^{125}$ I-NBT binding in the rat brain

\begin{tabular}{|c|c|c|c|c|c|}
\hline \multirow[b]{2}{*}{ Brain area } & \multicolumn{5}{|c|}{ Specific ${ }^{125}$ I-NBT binding $\left(\mathrm{amol} / \mathrm{mm}^{2}\right)$} \\
\hline & Total & & $\begin{array}{l}\text { In presence } \\
\text { of } 0.5 \mu \mathrm{M} \alpha \mathrm{BT} \\
\end{array}$ & & $\begin{array}{l}\text { In presence of } \\
\alpha \mathrm{BT}+100 \mu \mathrm{M} \\
\text { nicotine }\end{array}$ \\
\hline Amygdala (medial nuclei) & $19.4 \pm 5.3$ & & $15.3 \pm 3.5$ & & $16.1 \pm 4.4$ \\
\hline Caudate-putamen & $16.0 \pm 2.1$ & & $13.5 \pm 2.0$ & & $10.6 \pm 0.9$ \\
\hline Central gray & $14.3 \pm 1.6$ & $*$ & $10.8 \pm 2.7$ & & $10.7 \pm 1.6$ \\
\hline Corpus callosum & $9.3 \pm 0.8$ & & $7.6 \pm 0.7$ & & $8.3 \pm 1.3$ \\
\hline Cortex (frontal lobe) & $17.5 \pm 1.8$ & & $14.6 \pm 1.6$ & & $13.2 \pm 1.6$ \\
\hline Cortex (occipital lobe) & $15.4 \pm 1.0$ & & $13.7 \pm 2.2$ & & $11.9 \pm 1.7$ \\
\hline Dorsal tegmental nucleus & $64.9 \pm 16.4$ & $*$ & $12.5 \pm 1.9$ & $*$ & $6.1 \pm 0.7$ \\
\hline Fasciculus retroflexus & $17.6 \pm 1.4$ & & $17.6 \pm 2.0$ & $\dagger$ & $8.7 \pm 1.1$ \\
\hline Habenula (lateral nucleus) & $14.1 \pm 1.9$ & & $12.0 \pm 1.5$ & & $13.2 \pm 1.1$ \\
\hline Habenula (medial nucleus) & $28.3 \pm 3.7$ & $*$ & $22.1 \pm 3.5$ & $*$ & $10.6 \pm 1.1$ \\
\hline Hilus of dentate gyrus & $30.4 \pm 4.5$ & $*$ & $13.8 \pm 2.3$ & & $12.9 \pm 0.9$ \\
\hline Hippocampus (CA1) & $17.0 \pm 0.5$ & & $14.3 \pm 1.7$ & & $14.2 \pm 1.5$ \\
\hline Hypothalamus (ML) & $33.8 \pm 4.6$ & $*$ & $11.5 \pm 1.7$ & & $11.2 \pm 1.3$ \\
\hline Hypothalamus (MM) & $14.7 \pm 1.2$ & & $11.8 \pm 2.1$ & & $11.3 \pm 1.9$ \\
\hline Inferior colliculus & $15.6 \pm 0.8$ & & $13.7 \pm 2.5$ & & $9.9 \pm 2.1$ \\
\hline Interpeduncular nucleus & $14.2 \pm 1.9$ & & $12.2 \pm 2.0$ & & $9.0 \pm 1.3$ \\
\hline Lateral geniculate nucleus (dorsal) & $25.0 \pm 2.8$ & & $21.7 \pm 1.3$ & $\dagger$ & $10.6 \pm 1.3$ \\
\hline Lateral geniculate nucleus (ventral) & $27.1 \pm 2.5$ & $\dagger$ & $15.8 \pm 1.3$ & * & $11.0 \pm 2.1$ \\
\hline Medial geniculate nucleus & $15.1 \pm 0.6$ & & $9.2 \pm 3.8$ & & $8.0 \pm 2.6$ \\
\hline Medial terminal nucleus & $37.3 \pm 1.3$ & & $30.8 \pm 3.1$ & $\dagger$ & $9.1 \pm 1.3$ \\
\hline Olivary pretectal nucleus & $28.2 \pm 1.1$ & & $24.1 \pm 1.1$ & $\dagger$ & $10.5 \pm 1.5$ \\
\hline Septum (lateral nucleus) & $11.6 \pm 1.7$ & & $9.4 \pm 1.3$ & & $9.0 \pm 0.9$ \\
\hline Substantia nigra & $15.0 \pm 1.3$ & $*$ & $10.8 \pm 1.6$ & & $9.8 \pm 0.8$ \\
\hline Subthalamic nucleus & $34.0 \pm 3.9$ & $\dagger$ & $11.1 \pm 2.0$ & & $8.8 \pm 1.4$ \\
\hline Superior colliculus (SuG) & $41.9 \pm 4.9$ & $*$ & $24.2 \pm 3.9$ & * & $10.0 \pm 2.1$ \\
\hline Superior colliculus (non-SuG) & $20.2 \pm 0.8$ & $*$ & $13.4 \pm 2.9$ & & $9.9 \pm 1.3$ \\
\hline Thalamus (VPM-VPL) & $13.9 \pm 2.0$ & & $12.3 \pm 1.8$ & & $12.1 \pm 0.2$ \\
\hline Ventral tegmental area & $13.9 \pm 1.3$ & $*$ & $9.3+1.2$ & & $7.5 \pm 0.4$ \\
\hline
\end{tabular}

Twenty-micron sections were incubated for $1 \mathrm{hr}$ at $37^{\circ} \mathrm{C}$ in $2.0 \mathrm{nM}{ }^{125} \mathrm{I}-\mathrm{NBT}$. Values represent mean \pm SEM for $3-4$ rats in units of amol $/ \mathrm{mm}^{2}$. Nonspecific binding (i.e., binding in the presence of $0.5 \mu \mathrm{M}$ unlabeled NBT) has been subtracted. ML, medial mammillary nucleus (lateral part); MM, medial mammillary nucleus (medial part); VPM-VPL, ventroposteromedial and ventroposterolateral nuclei; SuG, superficial gray layer of the superior colliculus.

${ }^{*}, p<0.05 ;$ †. $p<0.0025$ by 1 -tailed paired $t$ test. The symbols are placed between pairs of values for which significant differences were detected.

buffer containing $2.0 \mathrm{nM}^{125} \mathrm{I}-\mathrm{NBT}$. Certain sections were incubated in the presence of $0.5 \mu \mathrm{M}$ nonradioactive NBT, $0.5 \mu \mathrm{M} \alpha \mathrm{BT}$ (Biotoxins Inc., St. Cloud, FL), $100 \mu \mathrm{M}$ nicotine (Sigma Chemical Co., St. Louis, MO), $100 \mu \mathrm{M} d$-tubocurare (CalBiochem, San Diego, CA), or $100 \mu \mathrm{M}$ dihydro- $\beta$-erythroidine (a gift from Merck Sharpe and Dohme, West Point, PA). These concentrations were found to be saturating when used as competing ligands in membrane binding studies (data not shown). After the incubation period, sections were washed twice for $30 \mathrm{~min}$ at $4^{\circ} \mathrm{C}$, first in buffer containing BSA and then in protein-free buffer. Washes of $30 \mathrm{~min}$ were found to minimize nonspecific binding, while causing no changes in the amount of specific binding observed when shorter (1 or $5 \mathrm{~min}$ ) wash periods were used. In some preliminary experiments, binding was quantitated by wiping each tissue section off the slide with a piece of filter paper and counting the paper in a gamma counter. However, in most experiments, the sections were blow dried at ambient temperature after washing and apposed to LKB Ultrafilm for 5-10 d. Sections were co-exposed with Amersham ${ }^{125} \mathrm{I}$ microscales (20 $\mu \mathrm{m}$ thickness, ranging in activity from 0.2 to $180 \mathrm{nCi} / \mathrm{mg}$ ) in order to convert optical density values on the film to units of radioactivity per mg tissue. A fourth-order polynomial function was used to relate optical density and radioactivity. In one experiment, the activity/optical density profiles of brain paste standards containing ${ }^{125}$ I were compared with those of the ${ }^{125} \mathrm{I}$ microscales, in order to determine an accurate conversion factor to be used in calculating receptor density values in tissue. The results were in close agreement with those oblained by Davenport and Hall
(1988); that is, tissue equivalent activities were approximately half those of the polymer microscales.

Quantitative analyses of the resulting autoradiograms were carried out using the MCID computerized image analysis system (Imaging Research Inc., St. Catharine's, Ontario). This system allows one to read the optical density of a square-shaped area, with the size of the square determined by the experimenter. In larger brain regions, several such randomly assigned areas were read, until well over $50 \%$ of a given brain region had been analyzed. The mean of these optical density $(O D)$ values was determined for a particular section, and a mean value for a single animal was obtained by examining at least 3 different sections. The mean \pm SEM values presented in Table 1 represent values determined by combining these results from $3-4$ different rats. With smaller brain regions (e.g., medial habenula), a single square of appropriate size was centered over each of the nuclei, and the bilateral optical densities were determined. The same size was used consistently for a given region. Variations in the data that could result from differences in the rostralcaudal localization of sections were minimized by assigning adjacent or near-adjacent sections to the different incubation conditions. All quantitative values are expressed as mean \pm SEM, with units for all data obtained from autoradiographic experiments expressed in $\mathrm{amol} / \mathrm{mm}^{2}$, as suggested previously (Clark and Hall, 1986; Davenport and Hall, 1988). Brain regions were identified in accordance with the atlas of Paxinos and Watson (1986). Analyses of variance were performed and revealed that there were regional differences in receptor densities. Paired 
A

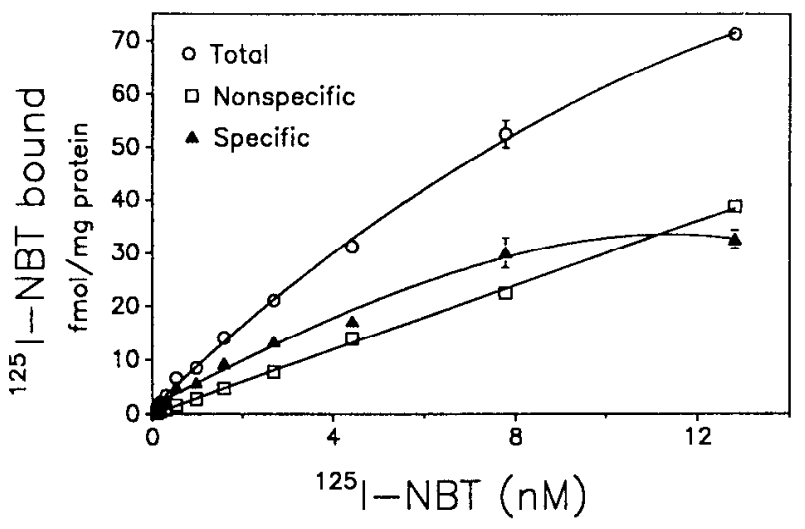

B

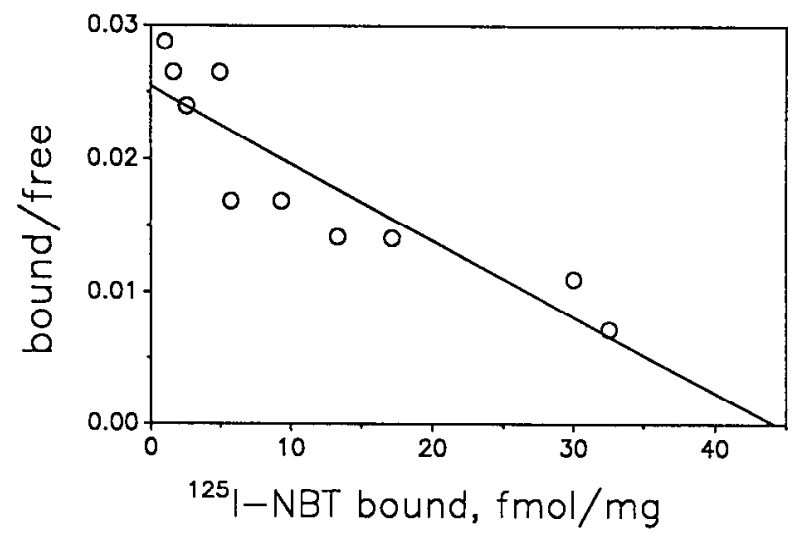

Figure 1. Concentration dependence of binding of ${ }^{125}$ I-NBT to rat striatal membranes. $A$, Total (circles), specific (triangles), and nonspecific (squares) binding, with each point representing mean \pm SEM for quadruplicate determinations. $B$, Scatchard transformation of data in $A$, yielding of $K_{d}$ of $6.7 \mathrm{nM}$ and a $B_{\max }$ of $44 \mathrm{fmol} / \mathrm{mg}$ protein.

$t$ tests (1-tailed) were then used to determine which regions contained significant densities of certain receptor subtypes.

\section{Results}

Because we had previously demonstrated that NBT is a functional nicotinic antagonist in rat striatal tissue, initial characterizations of ${ }^{125} \mathrm{I}-\mathrm{NBT}$ binding were performed using striatal membranes. Saturation data from a typical single experiment are shown in Figure $1 A$, and a Scatchard transformation is depicted in Figure $1 B$. Binding of ${ }^{125} \mathrm{I}-\mathrm{NBT}$ was found to be saturable and of high affinity, with 5 separate experiments yielding an average receptor density of $39 \pm 6 \mathrm{fmol} / \mathrm{mg}$ protein and an affinity constant of $4.6 \pm 0.6 \mathrm{~nm}$ (all values given are means \pm SEM). The ratio of total to nonspecific binding at $1 / 2$ the $K_{d}$ was approximately $2.7: 1$, though autoradiographic experiments revealed that this ratio varies for different brain regions. The Hill coefficient for binding was $0.95 \pm 0.08$, indicating no cooperativity. While appearing somewhat curvilinear, the data on computer analysis (Lundeen and Gordon, 1986) were best fit by a straight line.

The kinetic properties of ${ }^{125} \mathrm{I}-\mathrm{NBT}$ binding at $37^{\circ} \mathrm{C}$ were determined. Typical experiments showing the association and dissociation of binding are depicted in Figures $2 A$ and $3 A$, respectively, with linear transformations of these data shown in Figures
A

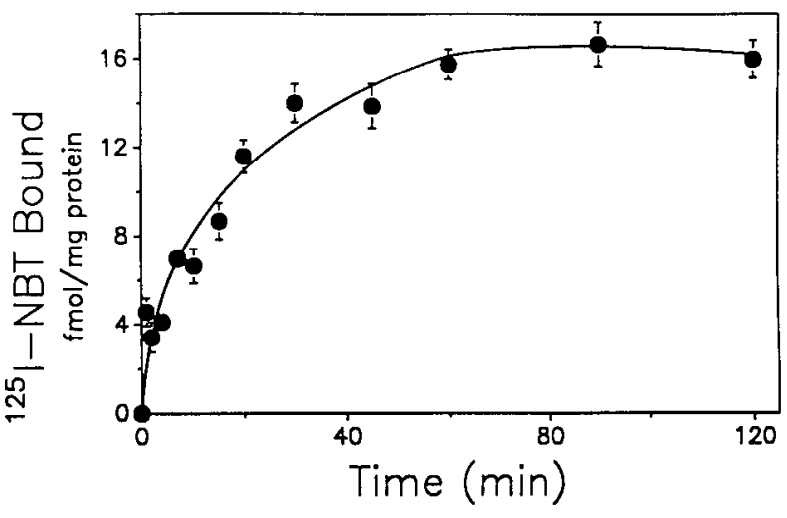

B

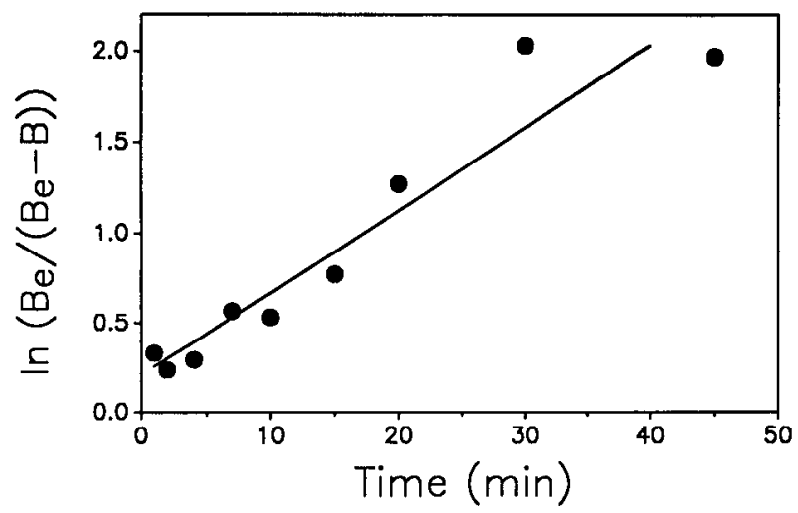

Figure 2. Association of ${ }^{125}$ I-NBT binding to striatal membranes. $A$, Washed membranes from rat striatum were incubated in $2.0 \mathrm{~nm}{ }^{125} \mathrm{I}-$ NBT for the indicated periods of time at $37^{\circ} \mathrm{C}$. The binding reaction was terminated by dilution with cold buffer, followed by rapid filtration. Each point represents mean \pm SEM for specific binding determined from quadruplicate determinations of both total and nonspecific binding. $B$, Linear transformation of the data from $A$, yielding a $k_{\mathrm{obs}}$ value of $0.04 \mathrm{~min}^{-1}$.

$2 B$ and $3 B$. As shown in Figure $2 A$, binding reached equilibrium by about $1 \mathrm{hr}$. Following determination of $k_{\text {obs }}$ and $k_{-1}$ values, the mean value for the association constant $\left(k_{+1}\right)$ was found to be $0.010 \pm 0.001 \mathrm{nM}^{-1} \mathrm{~min}^{-1}$. Interruption of equilibrium, either by addition of excess nonradioactive NBT $(0.5 \mu \mathrm{M})$ or by 40 -fold dilution with buffer, demonstrated that binding was reversible, though the dissociation was not clearly monophasic (Fig. $3 \mathrm{~A}$ ). After $4 \mathrm{hr}, 20 \%$ of the binding seen at equilibrium remained, while by $24 \mathrm{hr}$, dissociation was virtually complete. If a single component of dissociation is assumed, the $k_{-1}$ value calculated from these data is $0.020 \pm 0.003 \mathrm{~min}^{-1}$, yielding a $K_{d}$ of $2 \mathrm{nM}$. This is in fairly close agreement with the value obtained from Scatchard analysis; the 2.3-fold discrepancy may result from an underestimation of the $k_{-1}$, because its calculation was based on the assumption of a monophasic dissociation (see Fig. 3B).

Autoradiographic data are presented as representative autoradiograms (as in Figs. 4, 6, 7) and as means \pm SEM of densitometric measurements of selected regions from a number of sections taken from several animals (Table 1). A preliminary determination of the time course of the binding of ${ }^{125}$ I-NBT to brain sections confirmed that, as with membrane preparations, $1 \mathrm{hr}$ was an appropriate incubation period to use in performing autoradiographic experiments (data not shown). It was also 
demonstrated that optimal specific to nonspecific binding ratios in tissue sections could be obtained by washing the sections twice for $30 \mathrm{~min}$ in ice-cold buffer (data not shown).

The binding of $2.0 \mathrm{nM}^{125} \mathrm{I}-\mathrm{NBT}$ alone at the level of the caudal thalamus is shown in Figure 4A. Areas with particularly dense labeling at this level include the lateral geniculate nucleus, the olivary pretectal nucleus, the medial mammillary nucleus (lateral part), and the fasciculus retroflexus. Competition studies established that NBT bound to 3 pharmacologically distinct sites. One class of sites was recognized by both NBT and $\alpha \mathrm{BT}$, as shown by incubating adjacent sections with (Fig. $4 B$ ) and without (Fig. $4 A$ ) nonradioactive $\alpha \mathrm{BT}(0.5 \mu \mathrm{M})$. Thus, as seen in Figure 4, $\alpha \mathrm{BT}$ largely abolished NBT binding in the medial mammillary nucleus (lateral part) and reduced it substantially in the lateral geniculate. Figure $4 B$ depicts those NBT sites not recognized by $\alpha \mathrm{BT}$. To determine the nicotinic nature of these sites, sections were incubated in the presence of $100 \mu \mathrm{m}$ nicotine plus $\alpha$ BT (Fig. 4C). Note that nicotine competed for a significant component of the ${ }^{125}$ I-NBT binding that remains in the presence of $\alpha \mathrm{BT}$, for example, in the lateral geniculate nucleus and the olivary pretectal nucleus (cf. Fig. $4 B, C$ ). Nonspecific binding, as defined by binding in the presence of $0.5 \mu \mathrm{M}$ nonradioactive NBT (in addition to nonradioactive $\alpha \mathrm{BT}$ and nicotine), is illustrated in Figure $4 D$. Note that nicotine plus nonradioactive $\alpha$ BT did not compete for all of the saturable ${ }^{125}$ I-NBT binding (cf. Fig. $4 C, D$ ), suggesting that this final component of binding was not nicotinic in nature. This failure of nicotine to recognize all specific ${ }^{125}$ I-NBT sites was observed at all levels of the brain. However, the density of the portion of specific binding not recognized by nicotine or $\alpha \mathrm{BT}$ was found to be approximately the same in all brain regions examined. The indication that some regions are actually more densely labeled in the presence of nicotine (Fig. $4 C$ ) than in its absence (Fig. $4 B$ ) appears to be due to experimental variability and was not reproducible (see Table 1 for quantitative analysis from several animals).

Quantitative measurement of these pharmacologically distinct components of ${ }^{125}$ I-NBT binding is illustrated in Figure 5 from experiments on the superficial gray layer of the superior colliculus. Optical density values determined from the photographic film for the binding of $2.0 \mathrm{nM}^{125}$ I-NBT were converted to receptor density values (units in $\mathrm{amol} / \mathrm{mm}^{2}$ ). Of the total saturable ${ }^{125}$ I-NBT binding in this brain region, about $40 \%$ was competed for by $\alpha \mathrm{BT}$ and about 75\% by nicotine plus $\alpha \mathrm{BT}$. Note that, when $\alpha \mathrm{BT}(0.5 \mu \mathrm{M})$ and nicotine $(100 \mu \mathrm{M})$ were both included in the incubation medium, the density of labeled sites was no less than if only nicotine were added. This suggests that there are no sites recognized by $\alpha \mathrm{BT}$ that are not also recognized by a high concentration of nonradioactive nicotine $(100 \mu \mathrm{M})$.

Figure 6, $A-C$, presents typical autoradiograms depicting the binding of $2.0 \mathrm{~nm}^{125}$ I-NBT at 3 other levels of the brain under 3 experimental conditions. Autoradiograms in the left column represent binding in the absence of competing ligand; those in the middle column, binding in the presence of $0.5 \mu \mathrm{M} \alpha \mathrm{BT}$; and those in the right column, binding in the presence of $\alpha \mathrm{BT}$ and $100 \mu \mathrm{M}$ nicotine. Again, $\alpha \mathrm{BT}$ competes for only a part of ${ }^{125} \mathrm{I}$ NBT binding, while a portion of the remaining $\alpha$ BT-insensitive sites are recognized by nicotine. At the level of the caudateputamen, $\alpha \mathrm{BT}$ competes for binding in the endopiriform nucleus and islands of Calleja (Fig. 6A), while there are no areas at this brain level with notably high densities of $\alpha$ BT-insensitive, but nicotine-sensitive sites. More caudally (Fig. 6B), it can be seen that the high levels of binding in the subthalamic nucleus are
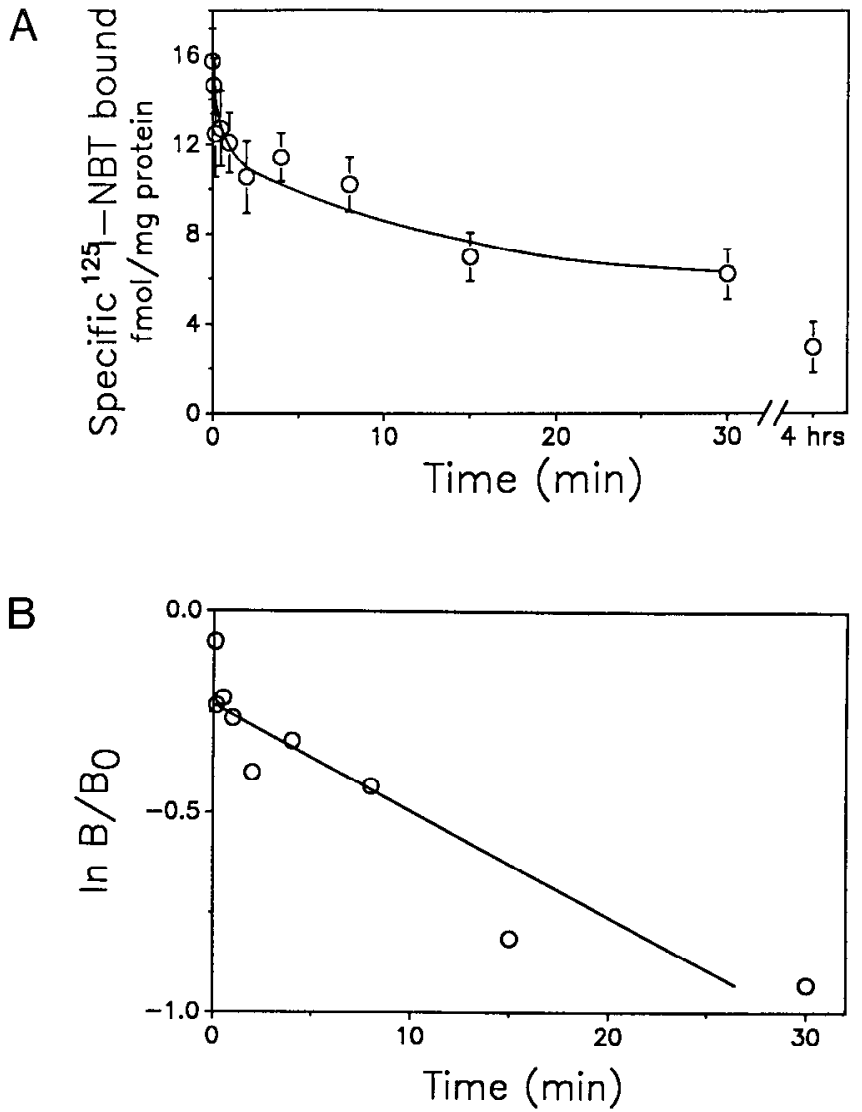

Figure 3. Dissociation of ${ }^{125}$ I-NBT binding from striatal membranes. $A$, Washed membranes from rat striatum were incubated in $2.0 \mathrm{nM}^{125} \mathrm{I}$ NBT for $90 \mathrm{~min}$ at $37^{\circ} \mathrm{C}$. In this experiment, equilibrium was interrupted by addition of unlabeled NBT $(0.5 \mu \mathrm{M})$. Dissociation kinetics did not differ if equilibrium was interrupted instead by dilution with buffer. Each point represents mean \pm SEM for specific binding resulting from quadruplicate determinations. $B$, Linear transformation of the data from $A$, yielding a $k_{-1}$ value of $0.025 \mathrm{~min}^{-1}$.

no longer detectable when $\alpha \mathrm{BT}$ is present as a competing ligand (middle autoradiogram). However, in the same figure, there is substantial ${ }^{125}$ I-NBT binding in the medial habenula in the presence of $\alpha$ BT. Similarly, $\alpha$ BT competes for only a portion of the dense labeling observed in the superficial gray layer of the superior colliculus and in the dorsal and medial terminal nuclei of the accessory optic tract (Fig. 6C, middlc autoradiogram). In the presence of nicotine, no selective labeling of these sites is seen (Fig. 6B,C, right autoradiograms). In addition, labeling is seen in an area of the hippocampal formation that seems to correspond to the hilus of the dentate gyrus (Fig. $6 \mathrm{C}$ ), and this labeling is competed for completely by $\alpha \mathrm{BT}$ (Table 1).

As seen in Figure 7, in sections taken from the level of the caudal superior colliculus, the nicotinic antagonists dihydro- $\beta$ erythroidine (Fig. $7 B$ ) and $d$-tubocurare (Fig. $7 C$ ) compete for $\alpha \mathrm{BT}$-resistant binding (Fig. 7A) in a manner that is similar to competition by the nicotinic agonist nicotine.

The density of ${ }^{125}$ I-NBT binding was compared for various regions of the brain after incubation with a single concentration $(2.0 \mathrm{nM})$ of ${ }^{125}$ I-NBT (Table 1). This concentration is slightly less than the $K_{d}$ for binding to striatal membranes. Thus, regional densities of total ${ }^{125}$ I-NBT binding sites cannot be directly detcrmincd from the table, becausc a subsaturating concentration 

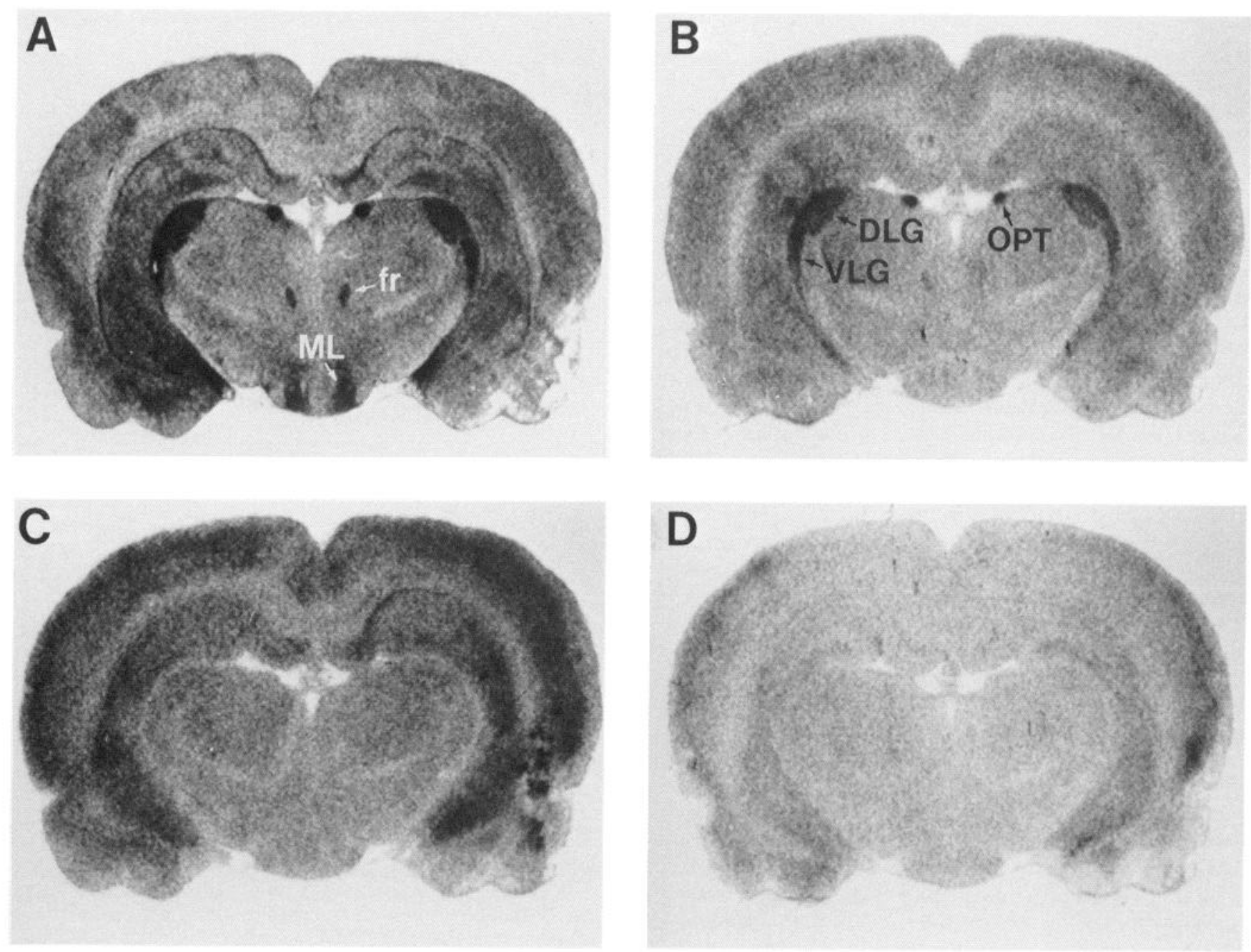

Figure 4. Binding of ${ }^{125} \mathrm{I}-\mathrm{NBT}(2.0 \mathrm{nM})$ to frozen rat brain sections at level of thalamus. Binding was examined under 4 conditions: $A$, Total binding. $B$, Binding in the presence of $0.5 \mu \mathrm{M}$ unlabeled $\alpha \mathrm{BT}$. $C$, Binding in the presence of $0.5 \mu \mathrm{M} \alpha \mathrm{BT}$ plus $100 \mu \mathrm{M}$ nicotine. $D$, Binding in the presence of $0.5 \mu \mathrm{M} \alpha \mathrm{BT}, 100 \mu \mathrm{M}$ nicotine, and $0.5 \mu \mathrm{M}$ unlabeled NBT. fr, fasciculus retroflexus; $M L$, medial mammillary nucleus, lateral part; $D L G$, dorsal lateral geniculate nucleus; $V L G$, ventral lateral geniculate nucleus; $O P T$, olivary pretectal nucleus. The apparent increased density in parts of the cortex and hippocampus in $C$, as compared with $B$, probably reflects experimental variability rather than an actual difference in extent of NBT binding (see Results and Table 1).

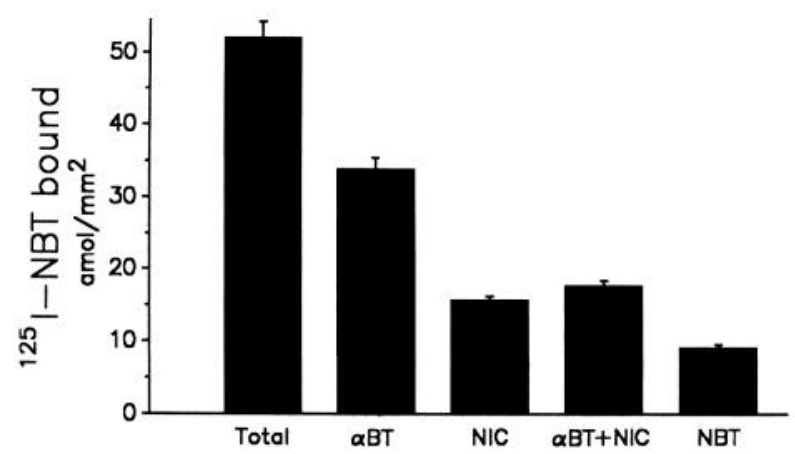

Figure 5. Quantitation of various pharmacological subtypes of ${ }^{125} \mathrm{I}-$ NBT binding sites. Optical density readings were taken from the superficial gray layer of the superior colliculus, and computer-assisted microdensitometry was used to determine receptor density values in $\mathrm{amol} / \mathrm{mm}^{2}$. ${ }^{125} \mathrm{I}-\mathrm{NBT}$ at a concentration of $2.0 \mathrm{nM}$ was present alone (Total) or in combination with the indicated competing ligands $[\alpha B T$ and $N B T$ at $0.5 \mu \mathrm{M}$; nicotine (Nic) at $100 \mu \mathrm{M}$ ]. of ${ }^{125} \mathrm{I}$-NBT was used. This list includes most regions where ${ }^{125} \mathrm{I}-$ NBT binding is particularly high. (Preliminary studies revealed that, while there were areas with high density of ${ }^{125}$ I-NBT binding in the pons and medulla, these sites were blocked totally by addition of nonradioactive $\alpha$ BT alone. These $\alpha$ BT-sensitive sites were not analyzed quantitatively.) Also included are areas where high densities of nicotinic receptors have been found by other methods (see introductory remarks), as well as representative nuclei from various regions commonly included in anatomical distribution studies (e.g., amygdala, cortex, hippocampus, hypothalamus, and thalamus). Nonspecific binding (i.e., binding in the presence of $0.5 \mu \mathrm{M}$ nonradioactive NBT) has been subtracted, so that the 3 columns listed in Table 1 are total specific binding, specific binding in the presence of $\alpha \mathrm{BT}(0.5 \mu \mathrm{M})$, and specific binding in the presence of $\alpha \mathrm{BT}$ and nicotine $(100 \mu \mathrm{M})$. Binding to sites shared by the 2 toxins (i.e., sites recognized by both NBT and $\alpha \mathrm{BT}$ ) may be determined by subtracting the values on the second column from those in the first. Areas with high densities of these sites include the dorsal tegmental nucleus, 

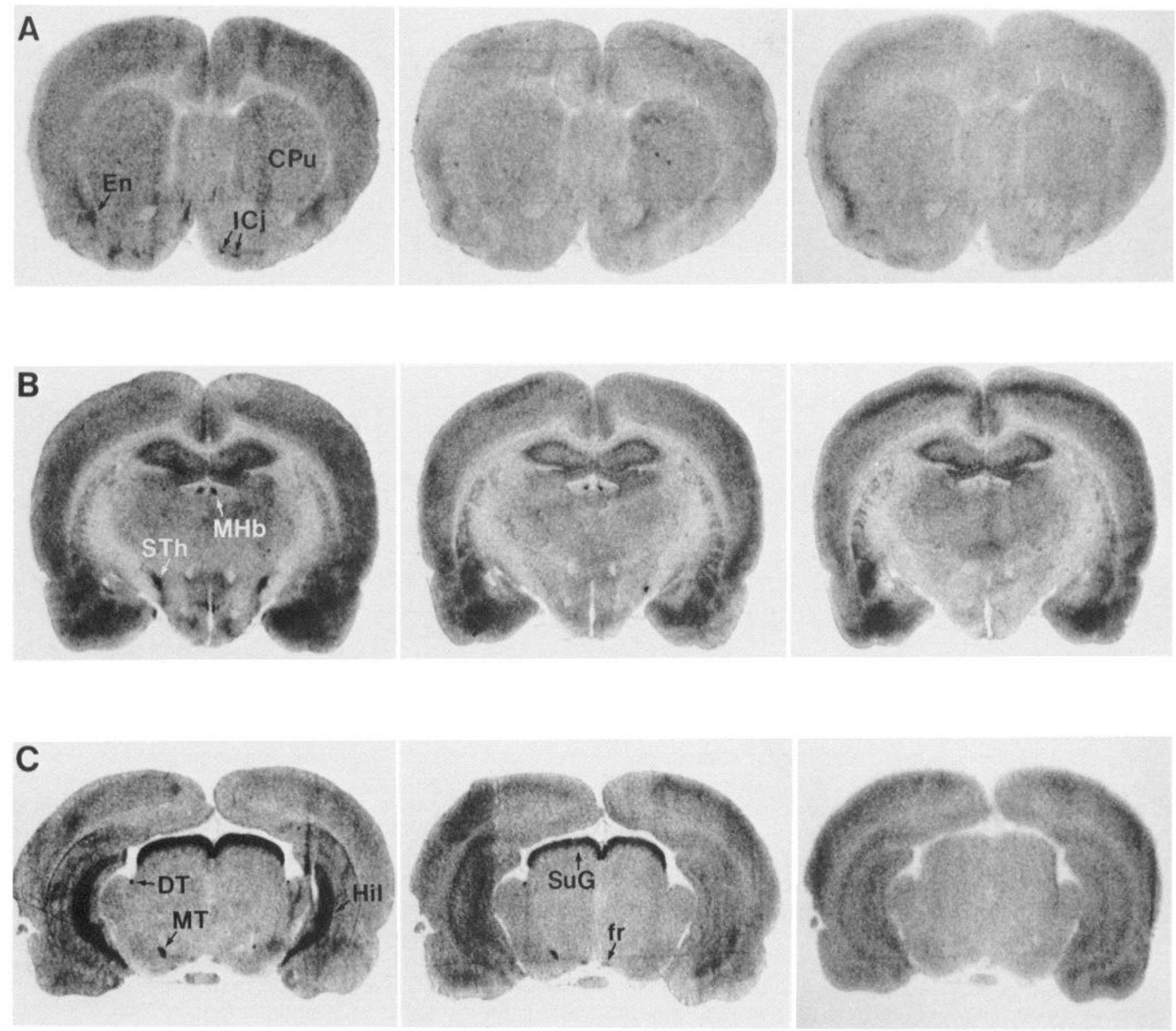

Figure 6. $A-C$, Binding of ${ }^{125}$ I-NBT ( $2.0 \mathrm{~nm}$ ) to frozen rat brain sections at 3 different levels of the rat brain, under the first 3 conditions described for Figure 4. Left autoradiograms, Total binding, no competing ligand; middle autoradiograms, $0.5 \mu \mathrm{M} \alpha \mathrm{BT} ;$ right autoradiograms, $0.5 \mu \mathrm{M} \alpha \mathrm{BT}$ plus $100 \mathrm{~mm}$ nicotine. $C P u$, caudate-putamen; $E n$, endopiriform nucleus; $I C j$, islands of Calleja; $M H b$, medial habenular nucleus; $S T h$, subthalamic nucleus; $D T$ and $M T$, dorsal and medial terminal nuclei of the accessory optic tract; $H i l$, hilus dentate gyrus; $S u G$, superficial gray layer of the superior colliculus; $f r$, fasciculus retroflexus.

the mediolateral nucleus of the hypothalamus, the hilus of the dentate gyrus, the ventral lateral geniculate nucleus, the subthalamic nucleus, and the superficial gray layer of the superior colliculus. The density of NBT-selective sites recognized by nicotine is obtained by subtracting values in the third column from those in the second. The areas with the greatest densities of these sites are the medial terminal nucleus of the accessory optic system, the superficial gray layer of the superior colliculus, the olivary pretectal nucleus, the dorsal lateral geniculate nucleus, the medial habenula, and the fasciculus retroflexus. The third category of saturable ${ }^{125}$ I-NBT binding sites, those that are not recognized by nicotine or $\alpha \mathrm{BT}$, are represented by the third column of Table 1 . Note that there is little regional heterogeneity with respect to the density of these sites.

\section{Discussion}

NBT is a neurotoxin that blocks nicotinic receptors in a variety of neuronal preparations, including several regions of the CNS. ${ }^{125}$ I-NBT has been extremely useful in characterizing and localizing nicotinic receptors in autonomic ganglia, and we have therefore examined its binding in the brain. The binding of ${ }^{125} I-$ NBT to membranes from the rat caudate-putamen was found to be saturable, reversible, and of high affinity. Values for the dissociation constant of the binding, whether determined by Scatchard or kinetic analyses, were similar (approximately 2-5 nM). It is likely that some of the striatal sites labeled by ${ }^{125} \mathrm{I}-$ NBT correspond to nicotinic receptors that are localized on dopaminergic nerve terminals, because nicotine-stimulated do- 

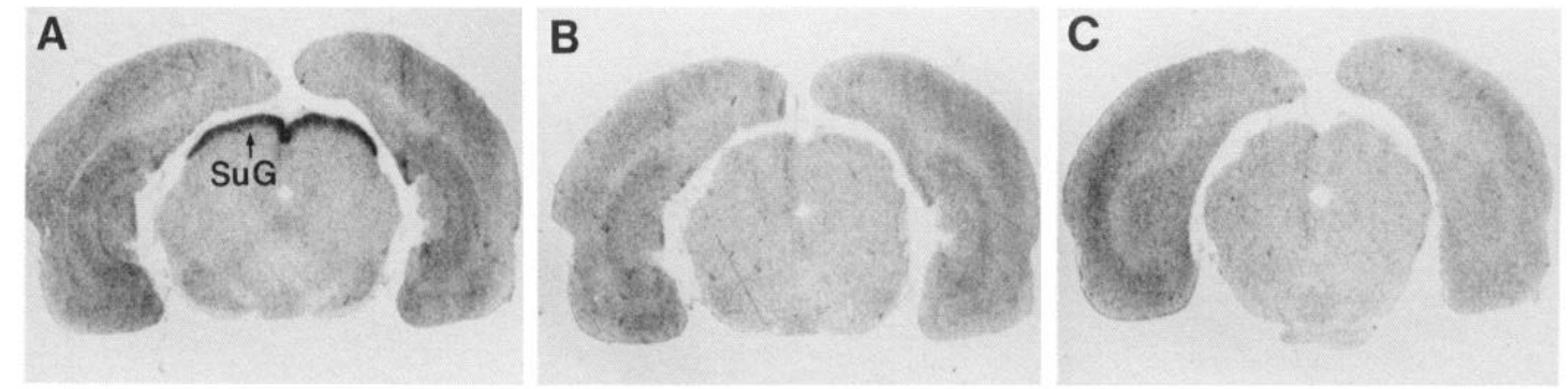

Figure 7. Binding of ${ }^{125} \mathrm{I}-\mathrm{NBT}(2.0 \mathrm{nM})$ to frozen rat brain sections at level of brain stem. The following competing compounds were present: left panel, $0.5 \mu \mathrm{M} \alpha \mathrm{BT}$; middle panel, $0.5 \mu \mathrm{M} \alpha \mathrm{BT}+100 \mu \mathrm{M}$ dihydro- $\beta$-erythroidine; right panel, $0.5 \mu \mathrm{M} \alpha \mathrm{BT}+100 \mu \mathrm{M} d$-tubocurare.

pamine release is potently blocked by NBT in striatal slices (Schulz and Zigmond, 1989). We have estimated that the $K_{i}$ of NBT for this inhibitory effect is approximately 5 nм (Schulz and Zigmond, 1989; D. W. Schulz and R. E. Zigmond, unpublished observations). The closeness between this value and the $K_{d}$ for striatal ${ }^{125}$ I-NBT binding provides indirect evidence that the ${ }^{125}$ I-NBT binding sites in the striatum are functional nicotinic receptors.

The autoradiographic data presented here demonstrate that the density of NBT binding sites is regionally very heterogeneous. Our studies also indicate that 3 pharmacologically distinct NBT binding sites exist in the brain, and that these can be distinguished by their affinity for $\alpha \mathrm{BT}$ and for nicotine. Previous workers have demonstrated that there is a very poor correlation between the central distributions of ${ }^{125} \mathrm{I}-\alpha \mathrm{BT}$ binding and ${ }^{3} \mathrm{H}$-nicotine binding (Marks and Collins, 1982; Schwartz et al., 1982; Clarke et al., 1985b). Thus, it was of particular interest to compare the distribution of binding sites for NBT, a compound that blocks functional nicotinic activity, with those for these other 2 ligands.

In the avian autonomic ganglia and retina, $\alpha \mathrm{BT}$ competes for some but not all ${ }^{125}$ I-NBT binding sites (Chiappinelli, 1983; Loring et al., 1984). The data presented here indicate that, in the rat brain as well, there exist at least 2 sites that bind NBT, only one of which recognizes $\alpha \mathrm{BT}$. $\alpha \mathrm{BT}$ has generally been found to be ineffective as an antagonist of neuronal nicotinic receptors. For example, $\alpha \mathrm{BT}$ fails to block the nicotine-mediated facilitation of dopamine release in the striatum, while, as noted above, NBT does block this effect (Schulz and Zigmond, 1989). Therefore, it is likely that, in the brain as in the periphery, functional blockade of nicotinic activity by NBT occurs at "NBT-selective" sites (i.e., sites not recognized by $\alpha \mathrm{BT}$ ). Thus, in addition to examining total and nonspecific ${ }^{125}$ I-NBT binding, we have localized NBT-selective sites in the brain by incubating anatomically adjacent sections with $0.5 \mu \mathrm{M}$ nonradioactive $\alpha \mathrm{BT}$ in order to mask sites that are also recognized by $\alpha \mathrm{BT}$. Note, when comparing the sections shown in Figure 6, that certain densely labeled areas (e.g., parts of the hippocampus and hypothalamus) are no longer prominently labeled when $\alpha \mathrm{BT}$ is present. In addition, $\alpha \mathrm{BT}$ partially blocks binding of NBT in other areas (e.g., the lateral geniculate). These areas have previously been found to be densely labeled when sections are incubated with nanomolar concentrations of ${ }^{125} \mathrm{I}-\alpha \mathrm{BT}$ (Segal et al., 1978; Marchand et al., 1979; Clarke et al., 1985b). However, the distribution of ${ }^{125} \mathrm{I}-\alpha \mathrm{BT}$ binding, for example, within the hippocampal and hy- pothalamic regions, is much more widespread than is the distribution of the "shared" ${ }^{225}$ I-NBT binding site, suggesting the possibility of multiple, pharmacologically distinct $\alpha \mathrm{BT}$ binding sites in the brain. In addition, it should be noted that, while $\alpha \mathrm{BT}$ has failed to block neuronal nicotinic receptors in vertebrates in most studies, there are some exceptions, raising the possibility that some of the $\alpha \mathrm{BT}$ binding sites in the brain may be functional nicotinic receptors.

Many of the NBT binding sites were not blocked by the presence of a high concentration of $\alpha \mathrm{BT}$. We used the classical nicotinic ligand nicotine to characterize further those $\alpha \mathrm{BT}$-insensitive sites. Areas with high densities of NBT sites recognized by nicotine but not recognized by $\alpha \mathrm{BT}$ include the medial habenula, the dorsal lateral geniculate nucleus, the olivary pretectal nucleus, the superficial gray layer of the superior colliculus, and the terminal nuclei of the accessory optic tract. All of these areas have been reported to contain high densities of nicotinic receptors, based on studies using ${ }^{3} \mathrm{H}$-nicotine autoradiography (Clarke et al., 1985b), immunohistochemical methods with monoclonal antibody 270 (Swanson et al., 1987), and measurement of ${ }^{14} \mathrm{C}$ 2-deoxyglucose utilization following intravenous administration of nicotine (London et al., 1988). However, ${ }^{125}$ I-NBT binding that is recognized by nicotine is far less widely distributed in the brain than is the labeling resulting from these other methodologies. For example, by comparing the second and third columns of Table 1 , it can be seen that this component of ${ }^{125}$ INBT binding is negligible in the substantia nigra, the ventral tegmental area, the medial geniculate nucleus, and most of the thalamus. In contrast, the studies cited above using other approaches all report high densities of nicotinic receptors in these regions.

By comparing the autoradiograms depicted in Figure 4, $C$ and $D$, it can be seen that a substantial portion of saturable ${ }^{125}$ I-NBT binding sites is not recognized by nicotine. Binding sites with similar properties have also been found in the chick retina (Loring et al., 1989), though the percentage of saturable ${ }^{125}$ I-NBT binding sites that fall into this category is lower in this tissue (approximately 10-15\%). These sites are fairly uniformly distributed in different regions of the rat brain. Furthermore, none of 15 different compounds that are pharmacologically active at various types of neurotransmitter receptors was found to recognize this site (e.g., atropine, fluphenazine, GABA, glutamate, glycine, naloxone; data not shown). Taken together, these observations raise questions concerning the functional significance of this category of ${ }^{125}$ I-NBT binding sites. 
As noted above, sites that are selectively labeled by ${ }^{125}$ I-NBT and recognized by nicotine are less widely distributed than either ${ }^{125} \mathrm{I}-\alpha \mathrm{BT}$ binding sites or high-affinity ${ }^{3} \mathrm{H}$-nicotine binding sites. Interestingly, these NBT binding sites appear to be restricted primarily to areas where primary visual afferent fibers are known to terminate. It has long been known that cholinergic neurotransmission exists in the mammalian retina (Masland and Ames, 1976; Ariel and Daw, 1982). At least one type of nicotinic receptor in retinal ganglion cells is recognized by NBT, because patch-clamp recordings from rat retinal ganglion cells in culture have demonstrated that responses to nicotinic agonists are potently blocked by NBT and not by $\alpha$ BT (Lipton et al., 1987; Aizenman et al., 1990). Furthermore, in the chick, there is a close correspondence between those areas of the retina exhibiting high ${ }^{125}$ I-NBT binding and those having intense ChAT immunoreactivity (Loring et al., 1989). As with the nigrostriatal system, it has been postulated that some nicotinic receptors synthesized by retinal ganglion cells may be transported down the optic nerve and optic tract, and ultimately reside on the axon terminals of these neurons (Francis and Schechter, 1980; Swanson et al., 1987). Because nicotinic receptors have been shown to affect neurotransmitter release in other systems (reviewed by Starke, 1981), it is possible that endogenously released ACh may modulate release of the transmitter utilized by primary visual afferent fibers via a direct action on presynaptically localized nicotinic receptors. The possibility that nicotinic transmission occurs in areas such as the superior colliculus and lateral geniculate nucleus is supported by anatomical studies demonstrating that these areas receive cholinergic afferent fibers that originate in the pontomesencephalic tegmentum (Mesulam et al., 1983; Woolf and Butcher, 1986). Answers to questions regarding the cellular localization of ${ }^{125}$ I-NBT binding sites in the brain, however, must await further study.

The relatively limited distribution of nicotinic ${ }^{125}$ I-NBT binding sites, compared to that of ${ }^{3} \mathrm{H}$-nicotine, raises the possibility that ${ }^{125}$ I-NBT may label a particular subtype of neuronal nicotinic receptors. The use of a cDNA clone coding for an $\mathrm{ACh}$ receptor $\alpha$ subunit from mouse muscle and low-stringency hybridization conditions has led to the isolation of several clones coding for putative neuronal nicotinic receptor $\alpha$ subunits $\left(\alpha_{2}\right.$, $\alpha_{3}$, and $\alpha_{4}$; Boulter et al., 1986, 1987; Goldman et al., 1986, 1987). There is now direct evidence that there is a family of at least 3 genes, each coding for a different neuronal $\alpha$ subunit (Nef et al., 1988). All of these subunits have structural homology to the muscle-type $\alpha$ subunit $\left(\alpha_{1}\right)$. In addition, several clones coding for a second type of subunit, a $\beta$ subunit, have been isolated, and it has been proposed that the complete neuronal nicotinic receptor consists of 1 or more $\alpha$ and 1 or more $\beta$ subunits (Boulter et al., 1987).

The central distributions of mRNAs coding for the $\alpha_{2}, \alpha_{3}$, and $\alpha_{4}$ subunits have now been described (Goldman et al., 1986, 1987; Wada et al., 1989), making it possible to compare the localizations of the expression of these subunits with the localization of ${ }^{125}$ I-NBT binding sites. Of course, it is impossible to make direct comparisons between results obtained using these 2 methodologies. In situ hybridization identifies cell bodies that contain the mRNA that encodes a particular protein; however, the protein itself may be concentrated in another part of the neuron (e.g., the nerve terminal). This issue is of particular importance if one considers the possibility that some nicotinic receptors may be axonally transported over distances of several millimeters in the brain. Nevertheless, it is still informative to compare the results from in situ hybridization with the present findings concerning the localization of ${ }^{125}$ I-NBT binding sites in the rat brain.

Overall, there is no obvious correspondence between the distribution of ${ }^{125} \mathrm{I}-\mathrm{NBT}$ binding sites and the presence of mRNA coding for any of the $3 \alpha$ subunits that have been characterized thus far. Expression of the $\alpha_{2}$ gene in the rat brain appcars to be restricted to the interpeduncular nucleus, an area that does not have appreciable ${ }^{125}$ I-NBT binding (Boulter et al., 1986). The distributions of expression of $\alpha_{3}$ and $\alpha_{4}$ genes are much more extensive than that of $\alpha_{2}$, but include areas where little ${ }^{125} \mathrm{I}-\mathrm{NBT}$ binding is detected (Wada et al., 1989). However, in light of the high densities of ${ }^{125}$ I-NBT binding sites found in areas receiving projections from the retina, it is interesting to note that both the $\alpha_{3}$ and $\alpha_{4}$ genes are expressed in retinal ganglion cells (Wada et al., 1989).

When the $\alpha_{2}$ subunit was expressed in frog oocytes together with the $\beta$, subunit, a functional nicotinic receptor was formed that was not blocked by NBT or by $\alpha$ BT (Wada et al., 1988). However, when either the $\alpha_{3}$ or the $\alpha_{4}$ subunit mRNA was injected with the $\beta_{2}$ subunit mRNA, the nicotinic receptor that was formed was blocked by NBT, though not by $\alpha \mathrm{BT}$ (Boulter et al., 1987). Interestingly, the potency of NBT is considerably higher for blocking the combination $\alpha_{3} \beta_{2}$ than for the combination $\alpha_{4} \beta_{2}$ (Luetje and Patrick, 1989). The issue of functional blockade is especially important when one considers that ${ }^{125} \mathrm{I}$ NBT binding is relatively low in the cortex and the caudateputamen, 2 regions where NBT has been shown to block nicotinic activity in brain slices in vitro (Schulz and Zigmond, 1989; Vidal and Changeux, 1989). Thus, it is unlikely that NBT blockade of nicotinic receptor-mediated effects is restricted only to those areas prominently labeled by ${ }^{125}$ I-NBT in the present study. Finally, it has recently been found that injection of oocytes with mRNA for the $\alpha_{3}$ subunit and for the newly discovered $\beta_{4}$ subunit leads to the formation of a nicotinic receptor that is insensitive to NBT (Duvoisin et al., 1989), indicating that the relationship between NBT sensitivity and, probably, binding and the presence of a particular $\alpha$ subunit in a neuron may be complex. This complexity is illustrated by the recent report of Mulle and Changeux (1990) that a nicotinic response recorded from enzymatically dissociated neurons from the habenula of 10-20d-old rats is blocked neither by $\alpha \mathrm{BT}$ nor by NBT. In situ hybridization studies indicate that the medial habenula contains mRNA for the $\alpha_{3}, \alpha_{4}, \beta_{2}$ (Wada et al., 1989), and $\beta_{4}$ (Duvoisin et al., 1989) subunits, and furthermore, that these subunits are not uniformly distributed throughout the nucleus (Wada et al., 1989).

In conclusion, we have demonstrated that NBT, a neurotoxin that selectively blocks nicotinic responses in a variety of neuronal preparations, may be used as a high-affinity ligand to study nicotinic receptors in the rat brain. Specific binding sites for ${ }^{125}$ I-NBT may be divided into 3 categories: (1) those that are recognized by both NBT and $\alpha \mathrm{BT}$, (2) those that are not recognized by $\alpha \mathrm{BT}$ but are recognized by nicotine, and (3) those that are recognized only by nonradioactive NBT and not by other nicotinic ligands. Binding sites included in the first 2 categories are heterogeneously distributed in the brain. However, because NBT, but not $\alpha \mathrm{BT}$, blocks nicotinic responses in most neuronal preparations studied, it is proposed that the second category probably represents the "physiologically relevant" component of ${ }^{125}$ I-NBT binding. Areas with significantly high densities of these sites are the medial habenula and various 
regions that receive primary visual input from retinal ganglion cells. The relatively limited distribution of these sites suggests that ${ }^{125}$ I-NBT may bind to a particular subclass of nicotinic receptors in the brain. The regional localization of these sites, as described here, should aid future studies on the functional importance of nicotinic synaptic transmission in the brain.

\section{References}

Aizenman E, Loring RH, Lipton SA (1990) Blockade of nicotinic responses in rat retinal ganglion cells by neuronal bungarotoxin. Brain Res 517:209-214.

Ariel M, Daw NW (1982) Effects of cholinergic drugs on receptive field properties of rabbit ganglion cells. J Physiol (Lond) 324:135160.

Arimatsu Y, Seto A, Amano T (1978) Localization of $\alpha$-bungarotoxin binding sites in mouse brain by light and electron microscopic autoradiography. Brain Res 147:165-169.

Boulter J, Evans K, Goldman D, Martin G, Treco D, Heinemann S, Patrick J (1986) Isolation of a cDNA clone coding for a possible neural nicotinic acetylcholine receptor $\alpha$-subunit. Nature 319:368374.

Boulter J, Connolly J, Deneris E, Goldman D, Heinemann S, Patrick J (1987) Functional expression of two neuronal nicotinic acetylcholine receptors from cDNA clones identifies a gene family. Proc Natl Acad Sci USA 84:7763-7767.

Brown DA, Docherty RJ, Halliwell JV (1983) Chemical transmission in the rat interpeduncular nucleus in vitro. J Physiol (Lond) 341:655670.

Chiappinelli VA (1983) Kappa bungarotoxin: a probe for the neuronal nicotinic receptor in the avian ciliary ganglion. Brain Res 277:9-21.

Chiappinelli VA, Dryer SE (1984) Nicotinic transmission in sympathetic ganglia. Blockade by the snake venom neurotoxin kappa-bungarotoxin. Neurosci Lett 50:239-244.

Clark CR, Hall MD (1986) Hormone receptor autoradiography: recent developments. Trends Biochem Sci 11:195-199.

Clarke PBS, Kumar R (1983) The effects of nicotine on locomotor activity in nontolerant and tolerant rats. Br J Pharmacol 78:329-337.

Clarke PBS, Pert CB, Pert A (1984) Autoradiographic distribution of nicotine receptors in rat brain. Brain Res 323:390-395.

Clarke PBS, Hommer DW, Pert A, Skirboll LR (1985a) Electrophysiological actions of nicotine on substantia nigra single units. $\mathrm{Br} \mathrm{J}$ Pharmacol 85:827-835.

Clarke PBS, Schwartz RD, Paul SM, Pert CD, Pert A (1985b) Nicotinic binding in rat brain: autoradiographic comparison of $\left[{ }^{3} \mathrm{H}\right]$ acetylcholine, [ $\left.{ }^{3} \mathrm{H}\right]$ nicotine, and [ $\left.{ }^{125} \mathrm{I}\right]-\alpha$-bungarotoxin. J Neurosci 5:1307-1315.

Davenport AP, Hall MD (1988) Comparison between brain paste and polymer [ $\left.{ }^{125} \mathrm{I}\right]$ standards for quantitative receptor autoradiography. $\mathrm{J}$ Neurosci Meth 25:75-82.

de la Garza R, McGuire TS, Freedman R, Hoffer BJ (1987) Selective antagonism of nicotine actions in the rat cerebellum with $\alpha$-bungarotoxin. Neuroscience 23:887-891.

de la Garza R, Freedman R, Hoffer BJ (1989) $\kappa$-Bungarotoxin blockade of nicotine electrophysiological actions in cerebellar Purkinje neurons. Neurosci Lett 99:95-100.

Deutch AY, Holliday J, Roth RH, Chun LLY, Hawrot E (1987) Immunohistochemical localization of a neuronal nicotinic acetylcholine receptor in mammalian brain. Proc Natl Acad Sci USA 84:86978701.

Duvoisin RM, Deneris ES, Patrick J, Heinemann S (1989) The functional diversity of the neuronal nicotinic acetylcholine receptors is increased by a novel subunit: $\beta_{4}$. Neuron 3:487-496.

Egan TM, North RA (1986) Actions of acetylcholine and nicotine on rat locus coeruleus neurons in vitro. Neuroscience 19:565-571.

Farley GR, Morley BJ, Javel E, Gorga MP (1983) Single-unit responses to cholinergic agents in the rat inferior colliculus. Hearing Res 11: 73-91.

Francis A, Schechter N (1980) Putative cholinergic receptor activity in the deafferented rat superior colliculus. Brain Res 183:224-228.

Goldman D, Simmons D, Swanson LW, Patrick J, Heinemann S (1986) Mapping of brain areas expressing RNA homologous to two different acetylcholine receptor $\alpha$-subunit cDNAs. Proc Natl Acad Sci USA 83:4076-4080.
Goldman D, Deneris E, Luyten W, Kochhar A, Patrick J, Heinemann S (1987) Members of a nicotinic acetylcholine receptor gene family are expressed in different regions of the mammalian central nervous system. Cell 48:965-973.

Grenhoff J, Aston-Jones G, Svensson TH (1986) Nicotinic effects on the firing pattern of midbrain dopamine neurons. Acta Physiol Scand 128:351-358.

Hatton GI, Ho YW, Mason WT (1983) Synaptic activation of phasic bursting in rat supraoptic nucleus neurones recorded in hypothalamic slices. J Physiol (Lond) 345:297-317.

Hunt S, Schmidt J (1978) Some observations on the binding patterns of $\alpha$-bungarotoxin in the central nervous system of the rat. Brain Res 157:213-232.

Kuhar MJ, Unnerstall JR (1985) Quantitative receptor mapping by autoradiography: some current technical problems. Trends Neurosci 8:49-53.

Lindstrom J, Schoepfer R, Whiting P (1987) Molecular studies of the neuronal nicotinic acetylcholine receptor family. Mol Neurobiol 1: 281-337.

Lipton SA, Aizenman E, Loring RH (1987) Neural nicotinic responses in solitary mammalian retinal ganglion cells. Pfluegers Arch 410:3743

London ED, Waller SB, Wamsley JK (1985) Autoradiographic localisation of $\left[{ }^{3} \mathrm{H}\right]$ nicotine binding sites in rat brain. Neurosci Lett 53: 179-184.

London ED, Dam M, Fanelle RJ (1988) Nicotine enhances cerebral glucose utilization in central components of the rat visual system. Brain Res Bull 20:381-385.

Loring RH, Zigmond RE (1987) Ultrastructural distribution of [125I]toxin $\mathrm{F}$ binding sites in chick ciliary neurons: synaptic localization of a toxin that blocks ganglionic nicotinic receptors. Neuroscience 7:2153-2162.

Loring RH, Zigmond RE (1988) Characterization of neuronal nicotinic receptors by snake venom neurotoxins. Trends Neurosci 11:73-78.

Loring RH, Chiappinelli VA, Zigmond RE, Cohen JB (1983) Characterization of a snake venom neurotoxin which blocks nicotinic transmission in autonomic ganglia. Soc Neurosci Abstr 9:1143.

Loring RH, Chiappinelli VA, Zigmond RE, Cohen JB (1984) Characterization of a snake venom neurotoxin which blocks nicotinic transmission in the avian ciliary ganglion. Neuroscience 11:989-999.

Loring RH, Andrews D, Lane W, Zigmond RE (1986) Amino acid sequence of toxin $\mathrm{F}$, a snake venom neurotoxin that blocks neuronal nicotinic receptors. Brain Res 38:30-37.

Loring RH, Sah DWY, Landis SC, Zigmond RE (1988) The ultrastructural distribution of putative nicotinic receptors on cultured neurons from the rat superior cervical ganglion. Neuroscience 24:10711080.

Loring RH, Aizenman E, Lipton SA, Zigmond RE (1989) Characterization of nicotinic receptors in chick retina using a snake venom neurotoxin that blocks neuronal nicotinic receptor function. J Neurosci 9:2423-2431.

Lowry OH, Rosebrough NJ, Farr AL, Randall RJ (1951) Protein measurement with the Folin phenol reagent. J Biol Chem 193:265275.

Luetje CW, Patrick JW (1989) Members of the neuronal nicotinic acetylcholine receptor family display distinct pharmacological and toxicological properties. Soc Neurosci Abstr 15:677.

Lundeen JE, Gordon JH (1986) Computer analysis of binding data. In: Receptor binding in drug research (O'Brien R, ed), pp 31-49. New York: Marcel Dekker.

Marchand CMF, Hunt SP, Schmidt J (1979) Putative acetylcholine receptors in hippocampus and corpus striatum of rat and mouse. Brain Res 160:363-367.

Marks MJ, Collins AC (1982) Characterization of nicotine binding in mouse brain and comparison with the binding of $\alpha$-bungarotoxin and quinuclidinyl benzilate. Mol Pharmacol 22:554-564.

Marshall LM (1981) Synaptic localization of $\alpha$-bungarotoxin binding which blocks nicotinic transmission at frog sympathetic neurons. Proc Natl Acad Sci USA 78:1948-1952.

Masland RH, Ames A (1976) Responses to acetylcholine of ganglion cells in an isolated mammalian retina. J Neurophysiol 39:1220-1235.

McCormick DA, Prince DA (1987) Acetylcholine causes rapid nicotinic excitation in the medial habenular nucleus of guinea pig, in vitro. J Neurosci 7:742-752.

Mesulam M-M, Mufson EI, Wainer BH, Levey AI (1983) Central 
cholinergic pathways in the rat: an overview based on an alternative nomenclature (Ch1-Ch6). Neuroscience 10:1185-1201.

Misgeld U, Weiler MH, Bak IJ (1980) Intrinsic cholinergic excitation in the rat neostriatum: nicotinic and muscarinic receptors. Exp Brain Res 39:401-409.

Mulle C, Changeux J-P (1990) A novel type of nicotinic receptor in the rat central nervous system characterized by patch-clamp techniques. J Neurosci 10:169-175.

Nef P, Oneyser C, Alliod C, Couturier S, Ballivet M (1988) Genes expressed in the brain define three distinct neuronal nicotinic acetylcholine receptors. EMBO J 7:595-601.

Nordberg A, Winblad B (1986) Reduced number of $\left[{ }^{3} \mathrm{H}\right]$ nicotine and $\left[{ }^{3} \mathrm{H}\right]$ acetylcholine binding sites in the frontal cortex of Alzheimer brains. Neurosci Lett 72:115-119.

Paxinos G, Watson C (1986) The rat brain in stereotaxic coordinates. San Diego: Academic.

Pazdernik TL, Cross RS, Mewes K, Samson F, Nelson SR (1982) Superior colliculus activation by retinal nicotinic ganglion cells: a 2-deoxyglucose study. Brain Res 234:197-200.

Popot JL, Changeux JP (1984) Nicotinic receptor of acetylcholine: structure of an oligomeric integral membrane protein. Physiol Rev 64:1162-1239.

Pradhan SN, Bowling C (1971) Effects of nicotine on self-stimulation in rats. J Pharmacol Exp Ther 176:229-243.

Rainbow TC, Schwartz RD, Parsons B, Kellar KJ (1984) Quantitative autoradiography of nicotinic $\left[{ }^{3} \mathrm{H}\right]$-acetylcholine binding sites in rat brain. Neurosci Lett 50:193-196.

Ravdin PM, Berg DK (1979) Inhibition of neuronal acetylcholine sensitivity by a toxin from Bungarus multicinctus venom. Proc Natl Acad Sci USA 76:2072-2076.

Sah DWY, Loring RH, Zigmond RE (1987) Long-term blockade by toxin $\mathrm{F}$ of nicotinic synaptic potentials in cultured sympathetic neurons. Neuroscience 20:867-874.

Sahley TL, Berntson GG (1979) Antinociceptive effects of central and systemic administration of nicotine in the rat. Psychopharmacology 65:279-283.

Schmidt J (1988) Biochemistry of nicotinic acetylcholine receptors in the vertebrate brain. Int Rev Neurobiol 30:1-38.

Schmidt J, Hunt S, Polz-Tejera G (1980) Nicotinic receptors of the central and autonomic nervous system. In: Neurotransmitter receptors and drug action (Essman WB, ed), pp 1-45. New York: Spectrum.

Schulz DW, Zigmond RE (1989) Neuronal bungarotoxin blocks the nicotinic stimulation of endogenous dopamine release from rat striatum. Neurosci Lett 98:310-316.
Schulz DW, Aizenman E, White WF, Zigmond RE (1988) Autoradiographic localization of nicotinic receptors in rat brain using ${ }^{125} \mathrm{I}$ neuronal bungarotoxin. Soc Neurosci Abstr 14:1328.

Schwartz RD, McGee R, Kellar KJ (1982) Nicotinic cholinergic receptors labelled by $\left[{ }^{3} \mathrm{H}\right]$ acetylcholine in rat brain. Mol Pharmacol 22: $56-62$.

Segal M, Dudai Y, Amsterdam A (1978) Distribution of an $\alpha$-bungarotoxin-binding cholinergic nicotinic receptor in rat brain. Brain Res 148:105-119.

Shimohama S, Taniguchi T, Fujiwara M, Kameyama M (1986) Changes in nicotinic and muscarinic cholincrgic reccptors in Alzhcimer-typc dementia. J Neurochem 46:288-293.

Starke K (1981) Presynaptic receptors. Annu Rev Pharmacol Toxicol 21:7-30.

Swanson LW, Simmons DM, Whiting PJ, Lindstrom J (1987) Immunohistochemical localization of neuronal nicotinic receptors in the rodent central nervous system. J Neurosci 7:3334-3342.

Tripathi HL, Martin BR, Aceto MD (1982) Nicotine-induced antinociception in rats and mice: correlation with nicotine brain levels. $\mathbf{J}$ Pharmacol Exp Ther 221:91-96.

Vidal C, Changeux J-P (1989) Pharmacological profile of nicotinic acetylcholine receptors in the rat prefrontal cortex: an electrophysiological study in a slice preparation. Neuroscience 29:261-270.

Wada K, Ballivet N, Boulter J, Connolly J, Wada E, Deneris ES, Swanson LW, Heinemann S, Patrick J (1988) Functional expression of a new pharmacological subtype of brain nicotinic acetylcholine receptor. Science 240:330-334.

Wada E, Wada K, Boulter J, Deneris E, Heinemann S, Patrick J, Swanson LW (1989) Distribution of alpha2, alpha3, alpha4, and beta2 neuronal nicotinic receptor subunit mRNAs in the central nervous system: a hybridization histochemical study in the rat. J Comp Neurol 284:314-335.

Whitehouse PJ, Martino AM, Antuono PG, Lowenstein PR, Coyle JT, Price DL, Kellar KJ (1986) Nicotinic binding sites in Alzheimer's disease. Brain Res 371:146-151.

Wong LA, Gallagher JP (1989) A direct nicotinic receptor-mediated inhibition recorded intracellularly in vitro. Nature 341:439-442.

Woolf NJ, Butcher LL (1986) Cholinergic systems in the rat brain: III. Projections from the pontomesencephalic tegmentum to the thalamus, tectum, basal ganglia, and basal forebrain. Brain Res Bull 16: 603-637.

Zatz M, Brownstein MJ (1981) Injection of $\alpha$-bungarotoxin near the suprachiasmatic nucleus blocks the effects of light on nocturnal pineal enzyme activity. Brain Res 213:438-442. 